\title{
Barn Owl (Tyto alba) breeding biology in relation to breeding season climate
}

\author{
Alexandre Chausson • Isabelle Henry • \\ Bettina Almasi · Alexandre Roulin
}

Received: 1 June 2013/Revised: 21 August 2013/Accepted: 16 September 2013/Published online: 11 October 2013

(c) Dt. Ornithologen-Gesellschaft e.V. 2013

\begin{abstract}
Winter weather has a strong influence on Barn Owl (Tyto alba) breeding biology. Here, we analyzed the impacts of weather conditions on reproductive performance during the breeding season using data collected over 22 years in a Swiss Barn Owl population. Variations in rain and temperature during the breeding season played an important role in within-year variation in Barn Owl reproduction. An increase in rainfall during the period from 4 to 2 weeks preceding egg laying had a positive effect on clutch size. In contrast, fledgling body mass was negatively influenced by rainfall during the $24 \mathrm{~h}$ preceding the measurements. Finally, ambient temperature during the rearing period was positively associated with brood size at fledging. In conclusion, weather conditions during the breeding season place constraints on Barn Owl reproduction.
\end{abstract}

Keywords Climate - Reproduction - Tyto alba .

Weather

\section{Zusammenfassung}

\section{Der Einfluss der Witterung während der Brutzeit auf} die Brutbiologie der Schleiereule (Tyto alba)

Jährliche Unterschiede im Wetter im Winter und Unterschiede in den Nahrungsbedingungen kurz vor der

Communicated by F. Bairlein.

A. Chausson · I. Henry · A. Roulin $(\bowtie)$

Department of Ecology and Evolution, University of Lausanne, Building Biophore, 1015 Lausanne, Switzerland

e-mail: Alexandre.Roulin@unil.ch

B. Almasi

Swiss Ornithological Institute, 6204 Sempach, Switzerland
Brutperiode haben einen großen Einfluss auf die Brutbiologie der Schleiereule. Anhand eines Langzeitdatensatzes von 22 Jahren untersuchten wir verschiedene Wettereinflüsse auf die Fortpflanzungsleistung einer schweizerischen Schleiereulenpopulation. Regenmenge und Temperatur während der Brutsaison spielten eine wichtige Rolle, um den individuellen Unterschied in der Fortpflanzung der Schleiereulenpaare zu erklären. Je mehr es während vier bis zwei Wochen vor Legebeginn regnete, desto grösser war das Gelege. Die Körpermasse der Nestlinge kurz vor dem Ausfliegen war dagegen durch Regen während 24 Stunden vor der Messung beeinträchtigt. Auch hatte die Umgebungstemperatur während der Aufzuchtzeit einen positiven Effekt auf die Anzahl Nestlinge, die bis zum Ausfliegen überlebten. Zusammenfassend kann gesagt werden, dass sich die Wetterbedingungen während der Brutsaison limitierend auf die Fortpflanzung der Schleiereulen auswirken.

\section{Introduction}

Meteorological and climatic factors explain substantial portions of the observed variances in survival, rates of population change, and reproductive parameters (Altwegg et al. 2006; Glenn et al. 2011). In particular, climatic conditions during the breeding season are likely to influence reproduction. Breeding activities have to be timed appropriately so that climatic factors are most favorable and reproductive success is enhanced (Bourgault et al. 2010). For example, in arid environments where rain is the limiting factor because it dictates the availability of nutrients, rainfall is positively associated with laying date (Newton 1998). In North America, American Goldfinches 
(Carduelis tristis) associate the timing of breeding with the ripening of thistle seeds (Stokes 1950). The importance of such timing is highlighted by observations that mismatches in the timing of breeding and food resources due to climate change can have negative impacts on life history traits (Durant et al. 2007; Carey 2009). In temperate zones where rain is not the limiting factor, the breeding cycles are often controlled by temperature and food abundance patterns (Carey 2009), with birds laying earlier during warmer springs (Haywood 1993; Weatherhead 2005).

Weather and food availability also exert important constraints on incubation and rearing duties. For example, low temperatures significantly increase the costs of incubation in Blue Tits (Cyanistes caeruleus) (Haftorn and Reinertsen 1985) and offspring rearing in Great Tits (Parus major) (Tinbergen and Dietz 1994). During the reproductive season, when the male parent is hard pressed to find food for courtship, and when parents have to bring back food to feed the young, meteorological conditions which impair hunting success (such as rain) can be expected to have important consequences. In the Barn Owl (Tyto alba), rain impairs hunting success and the feeding rate (Michelat and Giraudoux 1992).

The aim of the study reported in the present paper was to investigate the impact of meteorological conditions during the Barn Owl breeding season. We predicted that high rainfall negatively affects reproductive success-mainly brood size and nestling body condition. The relationship with temperature during the breeding season on the other hand is, however, not clear; seasonally cold temperatures and heat waves (Charter et al. 2010) can both decrease reproductive success. Using 22 years of data, we determined whether meteorological conditions account for between-pair variation in reproductive success.

\section{Materials and methods}

Study area

Data were collected in western Switzerland between 1990 and 2011. The study area covers $1,070 \mathrm{~km}^{2}$ and consists primarily of agricultural land. Elevation ranges from 375 to $850 \mathrm{~m}$. Over the 22 years, we captured 1,022 adults and 4,209 young fledged from 207 different nest boxes. See Frey et al. (2010) for a scaled map of the study area.

\section{Breeding parameters}

The following breeding parameters were recorded: laying date, clutch size, egg length and width, number of unhatched eggs, nestling body mass, and number of fledglings. The laying date is defined as the date when the first egg of a clutch was laid, determined from the age of the first-hatched nestling at the first nest visit, and assuming a period of 32 days for incubation (Roulin 2004). Brood size at fledging was recorded when nestlings were approximately 55 days of age. At each visit, we measured nestling body mass to the nearest gram. Nestling sex was determined using sex-specific molecular markers from blood cell DNA from 1996 onwards (Py et al. 2006). The ages of re-captured breeding birds that had been ringed as nestlings were known; otherwise, the ages of breeding birds were estimated from their molt patterns (Taylor 1993). For each brood, mean egg length and width were calculated. The mean clutch size in our study area is 6 eggs, and eggs are laid on average 2.5 days apart, so a laying event lasts on average 15 days. See Frey et al. (2010) for additional details on how breeding parameters were recorded.

\section{Weather variables}

The meteorological variables were obtained from the Swiss Meteorological Institute (MeteoSwiss, Office fédéral de météorologie et de climatologie 2011) at a station in Payerne which is situated in the center of the study area. Daily weather data on precipitation $(\mathrm{mm})$ and temperature (daily mean ${ }^{\circ} \mathrm{C}$ ) were extracted. Figure 1 shows monthly means calculated from mean daily temperatures and precipitation sums.

\section{Statistical procedure}

All statistical analyses were done with the software JMP 7.0 (SAS Institute, Cary, NC, USA) or GLIMMIX with SAS v.9.1 (SAS Institute Inc.). Variables were considered significant when the corresponding $P$ value of the twotailed test was lower than 0.05. Assumptions for the parametric tests used (homoscedasticity and normal distributions of variables or residuals) were verified in each test. Means are quoted \pm SE. Because ambient temperature and precipitation are not independent, and also because we separated the weather data into successive time windows (see below), the number of intercorrelated variables is relatively high. To reduce the number of variables and obtain a limited number of relevant indices describing the weather, we used a technique that is commonly used in biology: principal component analysis (hereafter referred to as PCA). We only considered components with eigenvalues above 1 in the analyses; specific information on eigenvectors, eigenvalues, and the percentage of variance explained are given in Table 1. For all models, year was included as a random factor to eliminate the confounding effects of yearly variation in breeding success. Male and female identities were added as random factors to account for repeated sampling of recaptured individuals in different 

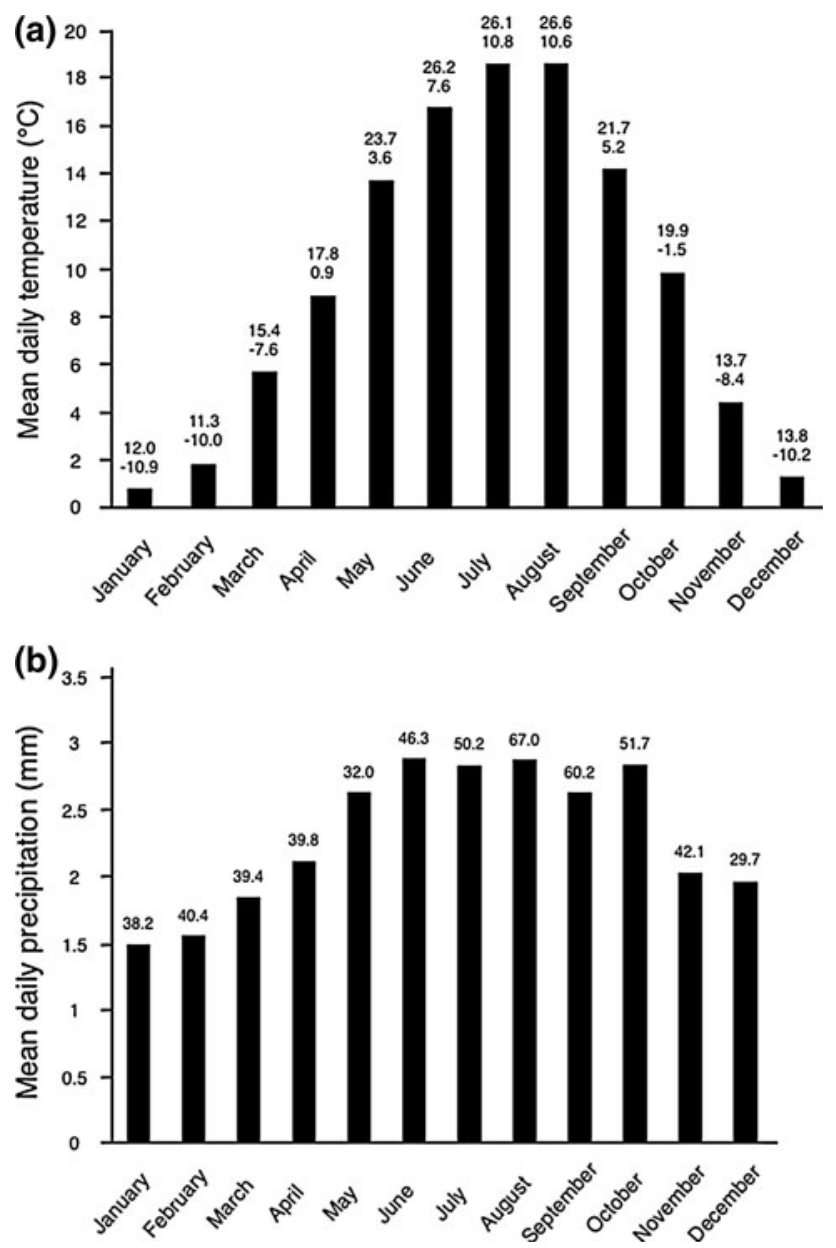

Fig. 1 Monthly mean daily temperature $\left({ }^{\circ} \mathrm{C}\right)$ (a) and mean daily precipitation $(\mathrm{mm})$ (b) between 1990 and 2011 in the center of the study area. Numbers above bars indicate maximal and minimal mean daily temperatures (a) as well as maximal daily precipitation (b) observed during the study period

years (except for the analysis of hatching success, for which only brood identity was entered as random variable; the analysis did not converge with more random factors). This is to control statistically for variation in factors intrinsic to the parents that may influence breeding success. Brood identity was added as a random factor to the fledging body mass analysis in order to account for repeated sampling of fledglings from the same brood.

To analyze the effects of temperature and precipitation on clutch size, hatching success, and fledging success by brood, we divided the period from 32 days before laying to 56 days after hatching into 15 periods of 8 days to obtain 4 periods before laying, 4 periods from the start of egg laying, and 7 periods from the start of egg hatching until fledging. The length of a period was chosen because it takes 32 and 56 days, respectively, for offspring to hatch and fledge, respectively (Taylor 1994). Note that while the chosen length of a period (8 days) has no particular biological meaning, it does allow us to discuss our results in terms of (approximately) weeks. The log-transformed total precipitation and the mean ambient temperature for each 8-day period were calculated for each brood. A summary of the statistical analyses and the sample sizes is given in Table 2.

To analyze the potential effect of precipitation and temperature on clutch size and egg size, we considered temperature and precipitation data for each of the four 8-daylong periods spanning from 32 days before egg laying to the start of egg laying (i.e., the weather conditions before the first egg was laid) and 8 days after the first egg of each brood had been laid (i.e., the weather conditions during egg laying). For precipitation, we extracted the first two principal components of a PCA based on those five periods; for temperature, the first principal component was extracted from a separate PCA based on the same five periods (Table 1a). We calculated the mean egg length and mean egg width for each clutch based on all of the eggs present.

We analyzed the relationship between hatching success (number of eggs that hatched divided by clutch size) and meteorological parameters during the 2 weeks preceding the laying of the first egg (egg formation lasts approximately 14 days, Durant et al. 2000), and during egg laying and incubation (the week during egg laying and the three subsequent weeks). For the two weeks of egg production, we extracted the first components of separate PCAs based on (1) the precipitation data and (2) the temperature data (Table 1). For the incubation period, we extracted the first two components of a PCA based on the precipitation data and the first component of a separate PCA based on the temperature data (Table 1b). We omitted data for unhatched eggs in 2011 because hatching success may have been impacted by corticosterone changes in nesting females. We restricted the analysis to nests that did not fail during the incubation period $(n=13)$.

We analyzed brood size at fledging in relation to the prevailing weather during the entire rearing period. We considered the seven 8-day periods from the start of hatching to 55 days later. For the temperature data, we extracted the first two components of a PCA; for the precipitation data collected during the same periods, we extracted the first three principal components from a separate PCA (Table 1c).

To investigate the relationship between body mass at fledging and meteorological data, we considered nestlings that were weighed between 44 and 56 days of age (mean \pm SE: $49.8 \pm 0.05$ ). We chose this age category because body mass is not significantly associated with age (Pearson's correlation: $r=-0.02, n=2,313, P=0.20$ ), which simplifies the analyses. The independent variables were sex (1,172 females and 11,141 males), hour of the day (1400 hours \pm 0.06 , range: 0200 hours -2300 hours), date 
Table 1 Results of principal component analyses to investigate the relationships of precipitation and temperature prior to and during egg laying to clutch size and egg size (a), the relationships of precipitation and temperature during egg formation and incubation to hatching success (b), and the relationships of precipitation and temperature during the rearing period to fledging (c)
The eigenvector is reported for each variable

\begin{tabular}{|c|c|c|c|c|c|}
\hline \multirow{3}{*}{$\begin{array}{l}\text { (a) Time periods for clutch and egg size analysis } \\
8 \text { days after the start of egg laying }\end{array}$} & \multicolumn{3}{|c|}{ Precipitation } & \multicolumn{2}{|c|}{ Temperature } \\
\hline & $\mathrm{pc} 1$ & $\mathrm{pc} 2$ & $\mathrm{pc} 3$ & $\mathrm{pc} 1$ & $\mathrm{pc} 2$ \\
\hline & -0.04 & 0.63 & & 0.45 & \\
\hline Week 1 before egg laying & 0.15 & 0.72 & & 0.45 & \\
\hline Week 2 before egg laying & 0.48 & 0.18 & & 0.45 & \\
\hline Week 3 before egg laying & 0.67 & -0.05 & & 0.45 & \\
\hline Week 4 before egg laying & 0.55 & -0.24 & & 0.44 & \\
\hline Eigenvalue & 1.39 & 1.14 & & 3.83 & \\
\hline Variance explained & 28 & 23 & & 77 & \\
\hline \multicolumn{6}{|l|}{ (b) Time periods for hatching success analysis } \\
\hline Week 2 before egg laying & 0.71 & & & 0.93 & \\
\hline Week 1 before egg laying & 0.71 & & & 0.93 & \\
\hline Eigenvalue & 1.09 & & & 1.71 & \\
\hline Variance explained & 54 & & & 87.2 & \\
\hline During egg laying & 0.50 & -0.42 & & 0.50 & \\
\hline Week 1 after egg laying & 0.67 & -0.13 & & 0.52 & \\
\hline Week 2 after egg laying & 0.53 & 0.29 & & 0.51 & \\
\hline Week 3 after egg laying & 0.16 & 0.85 & & 0.48 & \\
\hline Eigenvalue & 1.22 & 1.01 & & 3.18 & \\
\hline Variance explained & 31 & 25 & & 79.4 & \\
\hline \multicolumn{6}{|l|}{ (c) Time periods for fledging success analysis } \\
\hline During 8 days after the start of hatching & -0.004 & 0.65 & 0.12 & 0.38 & -0.43 \\
\hline 1 week later & -0.31 & 0.57 & -0.14 & 0.41 & -0.36 \\
\hline 2 weeks later & -0.44 & -0.24 & 0.27 & 0.43 & -0.21 \\
\hline 3 weeks later & 0.34 & -0.31 & -0.29 & 0.43 & 0.04 \\
\hline 4 weeks later & 0.52 & -0.01 & 0.40 & 0.40 & 0.23 \\
\hline 5 weeks later & 0.40 & 0.23 & 0.53 & 0.33 & 0.49 \\
\hline 6 weeks later & -0.40 & -0.23 & 0.61 & 0.23 & 0.59 \\
\hline Eigenvalue & 1.29 & 1.23 & 1.05 & 3.16 & 1.62 \\
\hline Variance explained & 18 & 18 & 0.15 & 45 & 23 \\
\hline
\end{tabular}

Clutch size

In a linear mixed model, clutch size increased with the first principal component of precipitation (linear mixed model: $\left.F_{1,678.2}=7.12, \quad P=0.0078\right)$ and tended to increase through the season $\left(F_{1,622.9}=3.60, P=0.058\right.$, estimate: $0.01 \pm 0.006$ egg per day); the second component of precipitation (Table 1a; $F_{1,831.8}=2.77, P=0.10$ ) and the first component of temperature $\left(F_{1,625.1}=0.09, P=0.76\right)$ were not significant. The random factors of female identity, male identity, and year significantly explained 19.8, 10.0, and $12.7 \%$ of the variance, respectively. Given the loadings of the different variables (Table 1a), we can conclude that clutches were larger when it rained more during the period from 8 to 24 days before egg laying. To determine which period is more strongly associated with clutch size, we ran another linear mixed model for each of the four periods before egg laying by including the same random factors and laying date as a covariate which was highly significant $(P<0.0001$; using estimates from the models, 
Table 2 Details of the statistical analyses performed on the reproductive parameters of Barn Owls

\begin{tabular}{|c|c|c|c|c|c|}
\hline Analysis & 8-day periods covered & $\begin{array}{l}\text { Principal components } \\
\text { of precipitation }\end{array}$ & $\begin{array}{l}\text { Principal components } \\
\text { of temperature }\end{array}$ & Sample size & $\begin{array}{l}\text { Number of breeding } \\
\text { adults }(+, \hat{\delta})\end{array}$ \\
\hline Clutch size & $\begin{array}{l}4 \text { before egg laying }+1 \text { during } \\
\text { egg laying }\end{array}$ & 2 & 1 & 900 nests & 483,404 \\
\hline $\begin{array}{l}\text { Mean egg } \\
\text { size }\end{array}$ & $\begin{array}{l}4 \text { before egg laying }+1 \text { during } \\
\text { egg laying }\end{array}$ & 2 & 1 & 782 nests & 429,359 \\
\hline $\begin{array}{r}\text { Hatching } \\
\text { success }\end{array}$ & $\begin{array}{l}2 \text { before egg laying }+2 \text { during } \\
\text { incubation/laying }\end{array}$ & 3 & 2 & 926 nests & 488,377 \\
\hline $\begin{array}{r}\text { Fledging } \\
\text { success }\end{array}$ & 7 during rearing & 3 & 2 & 809 nests & 427,357 \\
\hline $\begin{array}{l}\text { Fledgling } \\
\text { body mass }\end{array}$ & Between 44 and 56 days of age & & & $\begin{array}{l}\text { 2,313 nestlings } \\
\text { from } 645 \text { nests }\end{array}$ & 383,324 \\
\hline
\end{tabular}

The time periods during which we considered precipitation and temperature, the number of principal components for precipitation and temperature used in the analyses, and the sample size are shown

clutch size was on average 5.6 on 1 March and 7.2 on 1 August). Clutches were significantly larger when it rained more intensely 3 weeks $\left(F_{1,860.2}=6.58, \quad P=0.011\right.$; Fig. 3) but not $4\left(F_{1,804.2}=1.61, P=0.20\right), 2\left(F_{1,865.9}=\right.$ $3.01, P=0.08)$, or $1\left(F_{1,847.1}=3.24, P=0.07\right)$ week before egg laying. In this model, we removed nonsignificant variables one after the other, but retaining them in the final model did not modify our conclusion-that the effect of precipitation on clutch size is stronger in the third week before egg laying.

\section{Egg size}

In a linear mixed model, average egg length per clutch tended to decrease with clutch size (linear mixed model: $\left.F_{1,179.6}=3.86, P=0.05\right)$, but it was not significantly associated with laying date $\left(F_{1,50.74}=0.02, P=0.88\right)$, the first component of temperature (Table $1 \mathrm{a} ; F_{1,53.14}=0.95$, $P=0.33$ ), or the two components of precipitation $\left(F_{1,71.88}=0.31, P=0.58\right.$ and $\left.F_{1,1238.6}=1.13, P=0.29\right)$. The random factors of female and male identity and year explained 79.6, 3.5, and $0.2 \%$ of the variance, respectively. Upon removing the first component of temperature, eggs decreased in length with date $\left(F_{1,262.5}=14.80, P=0.0002\right.$; using estimates from the models, egg length was on average $39.7 \mathrm{~mm}$ on 1 March and $39.0 \mathrm{~mm}$ on 1 August).

In a separate linear mixed model, mean egg width was also associated with clutch size $\left(F_{1,182.4}=4.98, P=0.027\right.$; using estimates from the models, egg width was on average $30.7 \mathrm{~mm}$ in 10-egg clutches and $30.4 \mathrm{~mm}$ in 2-egg clutches), but was not associated with the first and second components of precipitation (Table $1 \mathrm{a} ; F_{1,62.09}=0.003, P=0.96$ and $\left.F_{1,231.2}=0.007, P=0.93\right)$, the first component of temperature $\left(F_{1,51.29}=0.05, \quad P=0.83\right)$, or laying date $\left(F_{1,47.27}=0, P>0.99\right)$. The random factors of female and male identity and year explained $75.3,0$, and $0.1 \%$ of the variance, respectively.
Hatching success

Hatching success was not related to any of the principal components (Table 1b) of precipitation and temperature obtained for the 14-day period before the laying of the first egg or for the first 32 days of incubation (GLIMMIX with the Poisson distribution and with year as a random factor; $P$-values $>0.10)$. In contrast, hatching success was lower in larger clutches (same model: $F_{1,908}=29.09, P<0.0001$ ) and tended to decrease through the season $\left(F_{1,908}=3.08\right.$, $P=0.08)$.

\section{Fledging success}

In a linear mixed model, the number of fledglings strongly declined through the season $\left(F_{1,191.2}=33.67, P<0.0001\right.$, using estimates $(-0.015 \pm 0.0027$ fledglings per day) from the model, the mean number of fledglings was 5.2 on 1 March and 2.8 on 1 August) after controlling for the number of hatchlings $\left(F_{1,617.1}=295.95, P<0.0001\right)$, and it was positively associated with the first principal component of temperature (Table $1 \mathrm{c} ; \quad F_{1,80.03}=11.64$, $P=0.001$; Fig. 4) but not with the second principal component of temperature $\left(F_{1,192.6}=0.23, P=0.63\right)$ or with the three principal components of precipitation (1st: $F_{1,684.6}=2.16, P=0.14 ; 2$ nd: $F_{1,621.7}=1.17, P=0.28$; $\left.3^{\text {rd. }} F_{1,576}=0.62, P=0.43\right)$. The random factors of female identity, male identity, and year explained 2.5, 8.7, and $0.6 \%$ of the variance, respectively. We can therefore conclude that fledging success declined through the season but increased when it was warmer, whereas rain had little effect.

\section{Fledging body mass}

Mean fledging body mass was negatively associated with the sum of precipitation the night before nestlings were 

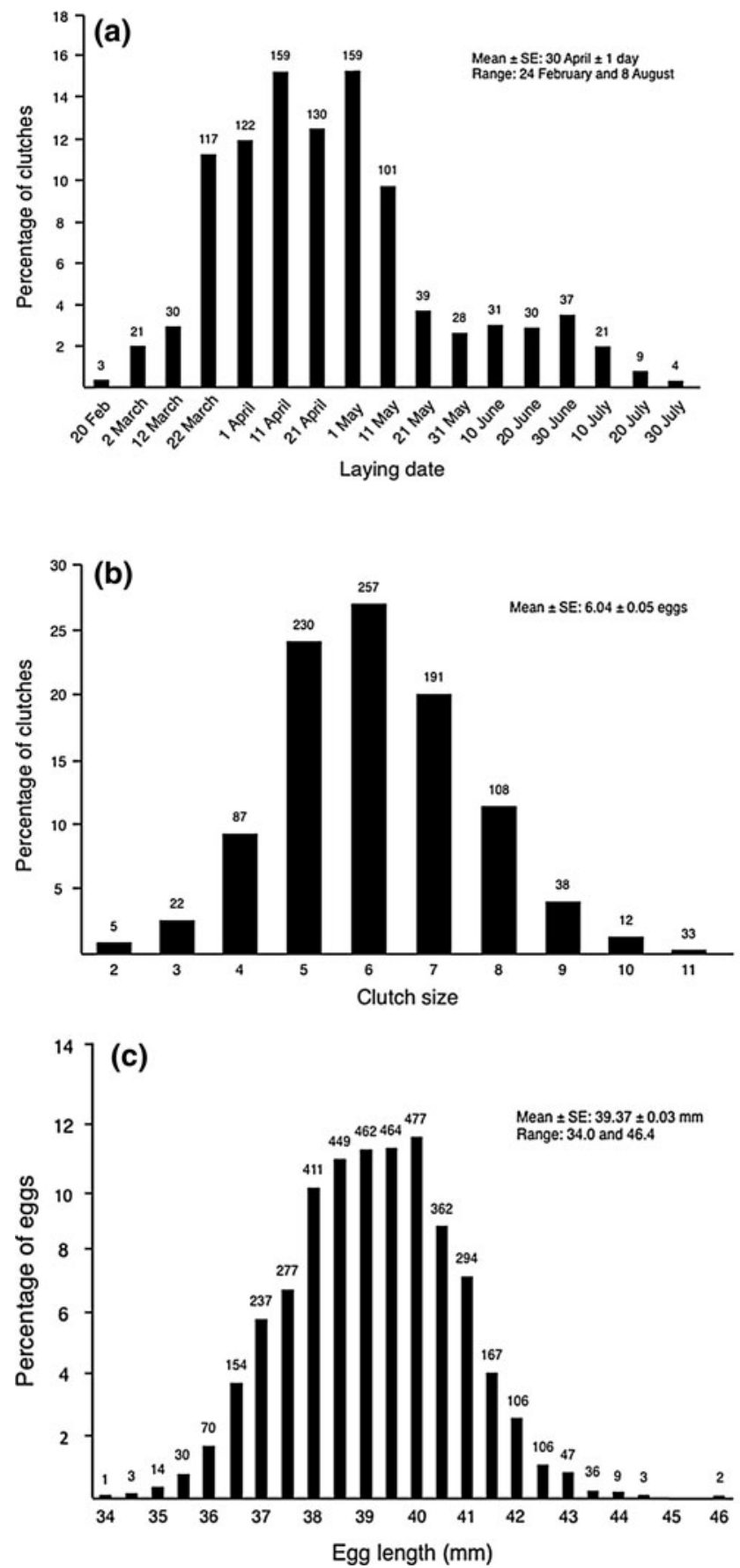

Fig. 2 Frequency distributions of laying dates (a), clutch sizes (b), egg length (c) and width (d), hatching success (e), and brood size at fledging (f) for Swiss Barn Owls. Sample sizes are given above the bars. The period covering all laying dates was divided into smaller

measured (linear mixed model, $F_{1,1939}=10.87, P=$ 0.0001; Fig. 5), but not the previous day $\left(F_{1,1993}=2.97\right.$, $P=0.09)$ or two nights before $\left(F_{1,1591}=0.37, P=0.54\right)$. In this model, we statistically controlled for nestling sex $\left(F_{1,2080}=187.16, P<0.0001\right.$; mean fledgling body mass was $346 \pm 1.2 \mathrm{~g}$ in males and $361 \pm 1.2 \mathrm{~g}$ in females),

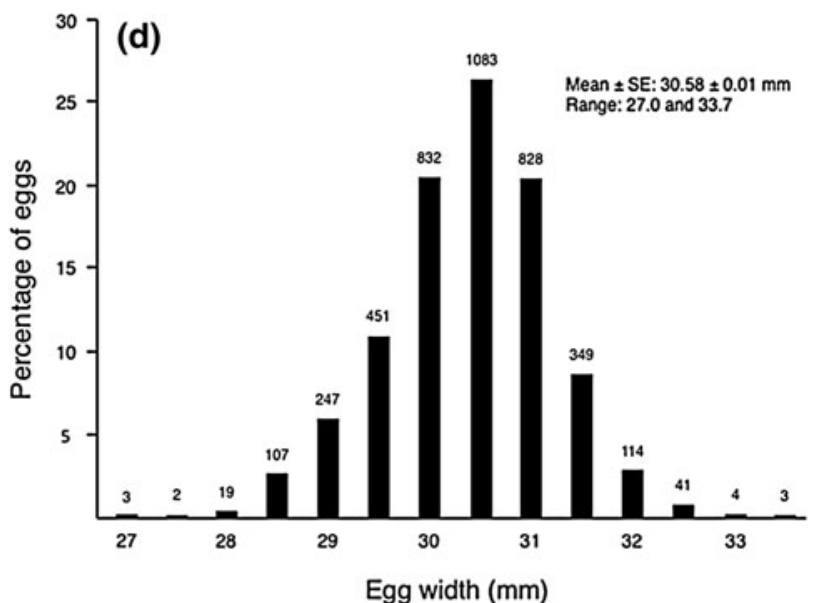

(e)
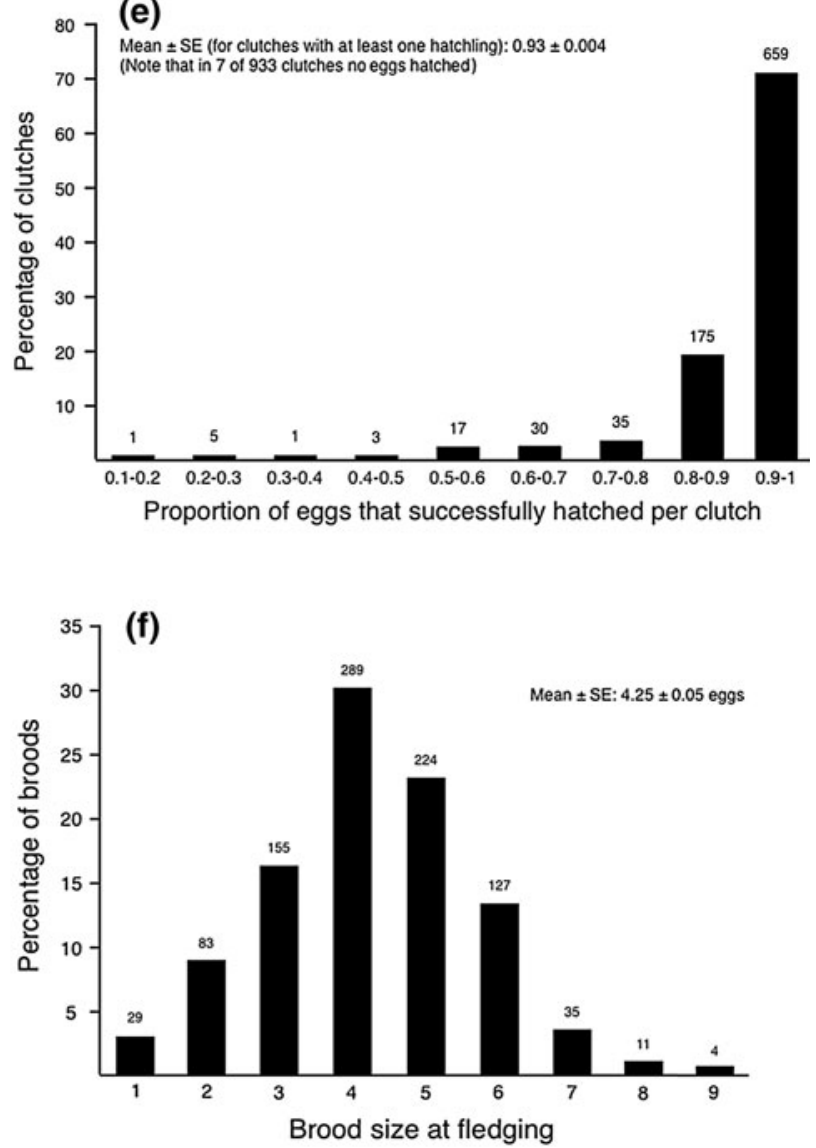

periods of 10 days. For example, a laying date in the period "1 May" refers to a clutch in which the first egg was laid between the 1st and 9th May. Mean and range are also reported in the panels

date $\left(F_{1,514.1}=41.42, P<0.0001\right.$; predicted mass is $370.8 \pm 16.1$ on 15 th April and $342.5 \pm 24.1$ on 15 th September); and hour of the day when nestlings were measured $\left(F_{1,1694}=75.48, P<0.0001\right.$; predicted mass is $366.6 \pm 2.4 \mathrm{~g}$ at 0700 hours and $341.2 \pm 1.87$ at 1900 hours). Fledging body mass was not associated with 


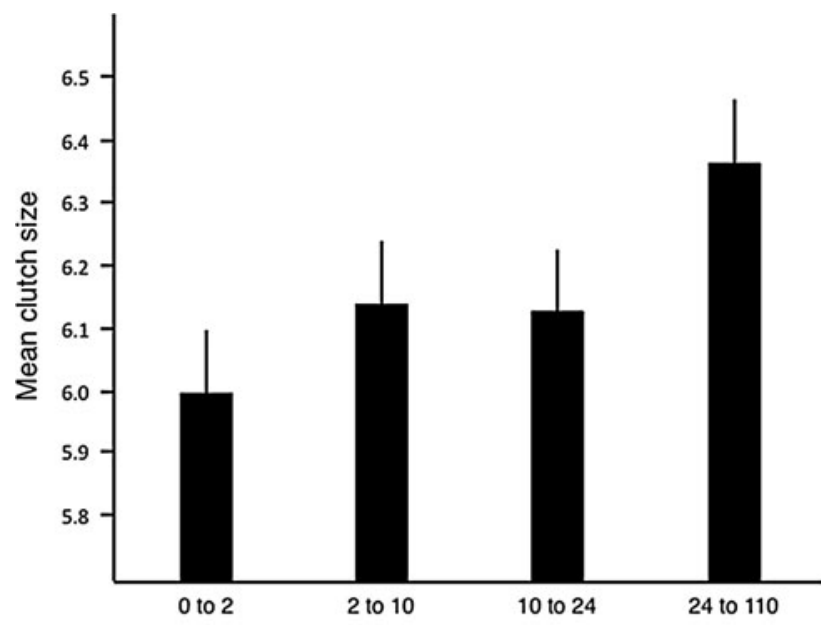

Total rainfall between 17 and 24 days before egg laying $(\mathrm{mm})$

Fig. 3 Relationship between the mean Barn Owl clutch size and the precipitation sum $(\mathrm{mm})$ between 24 and 17 days before laying. Precipitation data extracted from the linear mixed model presented in the results are retained to control for the effect of laying date. The data were divided into four categories of equal sample sizes according to precipitation amount. This figure indicates that clutches are larger when rainfall was more abundant in the third week before the start of egg laying

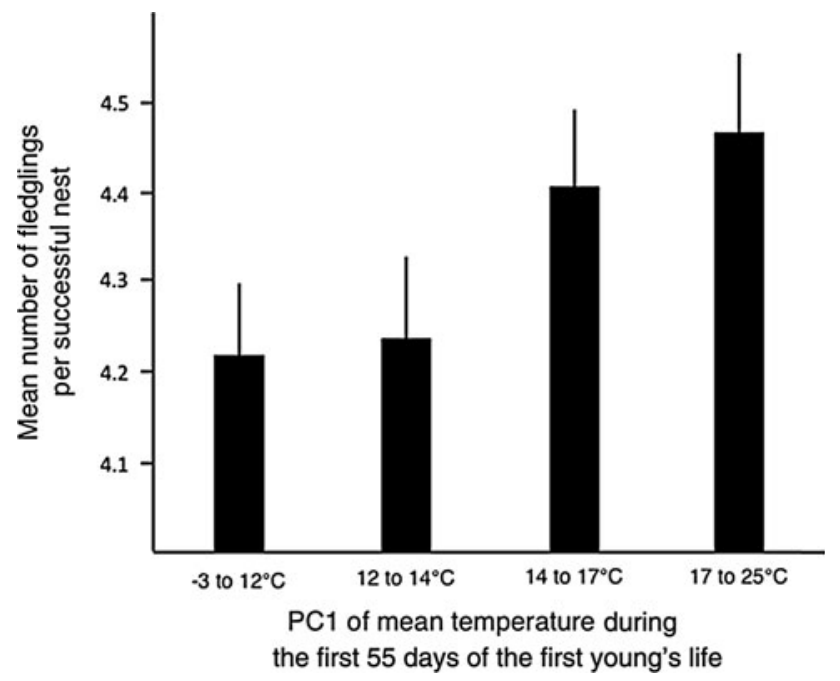

Fig. 4 Relationship between the mean number of Barn Owl fledglings and first principal component of average temperature. Mean $( \pm \mathrm{SE})$ temperature data extracted from the linear mixed model presented in the results are retained to control for laying date and hatch size. The data were divided into four categories of equal sample sizes. This figure indicates that brood size at fledging is larger when the temperature is higher throughout the rearing period

temperature the day before, 2 days before, or 3 days before $(P$-values $>0.40)$. The random factors of brood identity, female identity, male identity, and year explained 28.68, $4.49,0$, and $1.2 \%$ of the variance, respectively.

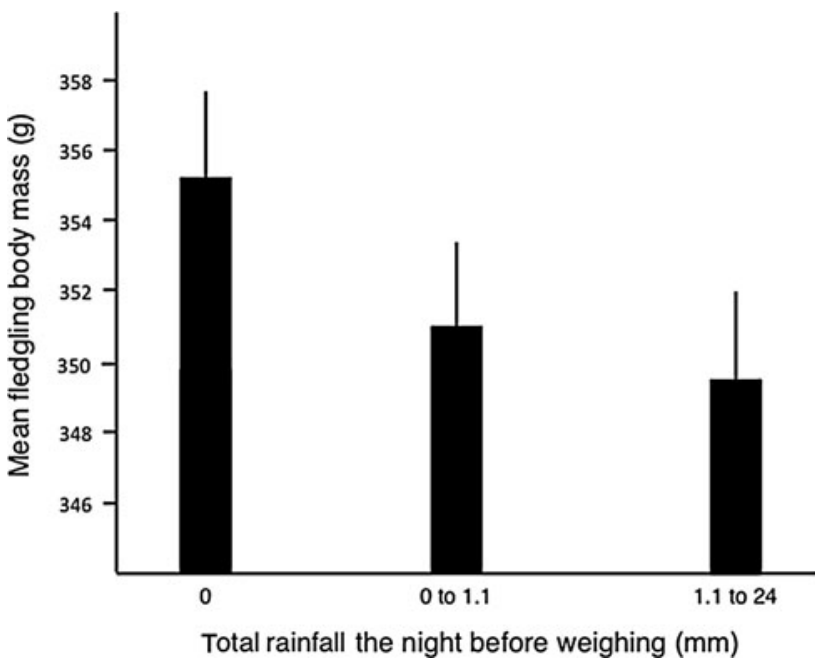

Fig. 5 Relationship between Barn Owl fledgling mass and total precipitation the night before the measure. Data for precipitation extracted from the linear mixed model presented in the results are retained to control for date, sex, and hour of the day. The data were divided into three categories of equal sample sizes. This figure indicates that fledgling are heavier following nights during which it did not rain

\section{Discussion}

Our results show that weather conditions during the breeding season had a major impact on reproductive parameters in a wild Barn Owl population in western Switzerland.

Clutch size, egg size, and hatching success

Clutch size increased through the season and with increasing precipitation 32-9 days prior to egg laying, with precipitation during the third period before the first egg was laid (24-17 days) having the strongest impact (Fig. 3). Given that Barn Owls may adjust clutch size according to the amount of food brought back by the male (Durant et al. 2010), and that rain impairs hunting success, it is surprising that larger clutches were observed with increasing amounts of rainfall prior to laying. Rain has been shown to have a rapid impact on clutch size; Patten and Rotenberry (1999) found that more rain 1 and 3 months prior to clutch completion led to larger clutches in the Blue Tit, and Lloyd (1999) found that Greybacked Finchlarks (Eremopterix verticalis) produced larger clutches just 1 week after abundant rains. Given that strong associations between clutch size and prey abundance have been observed in owls (Braaksma and De Bruijn 1976; Schönfeld et al. 1977; Korpimäki 1987; Taylor 1994; Gehlbach and Roberts 1997), higher amounts of rainfall may increase rodent activity (Vickery and Bider 1981) or may affect the soil or vegetation cover, improving rodent catchability. 
In a previous study on Great Tits, colder temperatures during egg production led to a reduction in egg volume of about $14 \%$ (Nager and Vannoordwijk 1992). We found no such relationship with egg length or width, but throughout the breeding season egg length decreased, and larger clutches tended to have shorter eggs. Given that Barn Owl clutch size increases throughout the breeding season, the latter observation does not come as a surprise.

The lack of any significant effect on hatching success of the ambient temperature and precipitation during the 32 days preceding egg laying is perhaps due to the fact that the time period considered here was too short to affect the mother's body condition, and hatching success can depend on the female's body condition, as it is energetically costly (Thomson et al. 1998; Reid et al. 2002; Kim and Monaghan 2006). Indeed, an unpublished study on the Barn Owl showed that the mean number of unhatched eggs observed during the subsequent breeding season was positively correlated with winter harshness (pers. obs.), suggesting that winter harshness induces lasting effects on female body condition that may affect hatching success. However, other studies on raptors have yielded results that suggest the opposite is true. For the Lesser Kestrel (Falco naumanni), Serrano et al. (2005) showed that warmer temperatures during the incubation period led to lower hatching success, but only for females in poor condition. In Israel, Charter et al. (2007) observed a population of Eurasian Kestrels (Falco tinnunculus), and found that higher minimum and mean temperatures during the breeding season led to lower hatching success.

\section{Fledging success and fledgling body mass}

Importantly, our results show that weather conditions during the breeding season may play a key role in determining fledgling success. The finding that reproductive success declines through the season but increases with temperature (which also increases through the season) indicates that the positive effect of temperature on brood size at fledging (Fig. 3) is not strong enough to offset the decline in rearing conditions later in the season. Interestingly, the strongest influence of temperature on the number of fledglings was seen from 8 to 39 days after the first egg hatched, the period when growth rate is maximal (Baudvin 1986).

We saw an impact of precipitation on nestling body mass $24 \mathrm{~h}$ before the measurements were carried out: nestling body mass was lower when it had rained more the previous night (Fig. 3). As rainy periods can hamper hunting success, this result can be explained by a decrease in the number of prey items brought back by the parents during rainy periods. Also, Martin et al. (2010) showed that Barn Owl nestlings in crop-harvested areas were lighter than nestlings in standing crop fields which support higher prey densities. It is interesting that the amount of rain that fell two nights prior to the measurements did not impact nestling weight. Most likely, the parents were able to bring back enough food the following night to offset the effects of the rain the night before. Thus, short-term rain events may not have a lasting impact on nestling body condition. This suggests that parents increase the feeding rate after a short-term period of poor hunting conditions, or that hunting conditions are better than average after a period of intense rain. However, longer periods of rain may severely impact nestling body condition of nestlings, which may lead to fledglings of lower quality which subsequently have poorer survival prospects.

Acknowledgments We are greatly indebted to Henri Etter and the late Martin Epars who helped collect the field data. We thank Dr. Martin Spiess and two anonymous reviewers for helpful comments on a previous draft, and Amélie Dreiss for statistical advice. The study was financed by grants from the Swiss National Science Foundation (grant nos. PPOA-102913 and 31003A_120517 to AR) and the Foundation De Giacomi.

\section{References}

Altwegg R, Roulin A, Kestenholz M, Jenni L (2006) Demographic effects of extreme winter weather in the barn owl. Oecologia 149:44-51

Baudvin H (1986) La reproduction de la chouette effraie Tyto alba. Le Jean-le-Blanc 25:1-125

Bourgault P, Thomas D, Perret P, Blondel J (2010) Spring vegetation phenology is a robust predictor of breeding date across broad landscapes: a multi-site approach using the Corsican blue tit Cyanistes caeruleus. Oecologia 162:885-892

Braaksma S, De Bruijn O (1976) De kerkuilstand in Nederland. Limosa 49:135-187

Carey C (2009) The impacts of climate change on the annual cycles of birds. Philos Trans R Soc Lond B 364:3321-3330

Charter M, Izhaki I, Bouskila A, Leshem Y, Penteriani V (2007) The effect of different nest types on the breeding success of Eurasian kestrels (Falco tinnunculus) in a rural ecosystem. J Rapt Res 41:143-149

Charter M, Meyrom K, Leshem Y, Aviel S, Izhaki I, Motro Y (2010) Does nest box location and orientation affect occupation rate and breeding success of barn owl Tyto alba in a semi-arid environment? Acta Ornithol 45:115-119

Durant JM, Massemin S, Thouzeau C, Handrich Y (2000) Body reserves and nutritional needs during laying preparation in barn owls. J Comp Physiol B Biochem Syst Environ Physiol 170:253-260

Durant JM, Hjermann DØ, Ottersen G, Stenseth NC (2007) Climate and the match or mismatch between predator requirements and resource availability. Clim Res 33:271-283

Durant JM, Gendner J, Handrich Y (2010) Behavioural and body mass changes before egg laying in the barn owl: cues for clutch size determination? J Ornithol 151:11-17

Frey C, Sonnay C, Dreiss A, Roulin A (2010) Habitat, breeding performance, diet and individual age in Swiss barn owls. J Ornithol 152:279-290

Gehlbach FR, Roberts JC (1997) Experimental feeding of suburban Eastern screech-owls Otus asio has few effects on reproduction apart from non-experimental factors. J Avian Biol 28:38-46 
Glenn EM, Anthony RG, Forsman ED, Olson GS (2011) Local weather, regional climate, and annual survival of the Northern spotted owl (Clima Local, Clima Regional y Supervivencia Anual de Strix occidentalis caurina). Condor 113:150-158

Haftorn S, Reinertsen RE (1985) The effect of temperature and clutch size on the energetic cost of incubation in a free-living blue tit (Parus caeruleus). Auk 102:470-478

Haywood S (1993) Role of extrinsic factors in the control of clutchsize in the blue tit Parus caeruleus. Ibis 135:79-84

Kim SY, Monaghan P (2006) Effects of early incubation constancy on embryonic development: an experimental study in the herring gull Larus argentatus. J Thermal Biol 31:416-421

Korpimäki E (1987) Timing of breeding of Tengmalm's Owl Aegolius funereus in relation to vole dynamics in western Finland. Ibis 129:58-68

Lloyd P (1999) Rainfall as a breeding stimulus and clutch size determinant in South African arid-zone birds. Ibis 141:637-643

Martin JM, Branch LC, Raid RN, Beyeler SC (2010) Temporal instability of agricultural habitat reduces reproductive success of barn owls Tyto alba. Auk 127:909-916

Michelat D, Giraudoux P (1992) Activité nocturne et stratégie de recherche de nouriture de la chouette effraie Tyto alba à partir du site de nidification. Alauda 60:3-8

Nager RG, Vannoordwijk AJ (1992) Energetic limitation in the egglaying period of great tits. Proc R Soc Lond B 249:259-263

Newton I (1998) Population limitations in birds. Academic, London

Patten MA, Rotenberry JT (1999) The proximate effects of rainfall on clutch size of the California gnatcatcher. Condor 101:876-880

Py I, Ducrest A-L, Duvoisin N, Fumagalli L, Roulin A (2006) Ultraviolet reflectance in a melanin-based plumage trait is heritable. Evol Ecol Res 8:483-489
Reid JM, Monaghan P, Ruxton GD (2002) Males matter: the occurrence and consequences of male incubation in starlings (Sturnus vulgaris). Behav Ecol Sociobiol 51:255-261

Roulin A (2004) The function of food stores in bird nests: observations and experiments in the barn owl Tyto alba. Ardea 92:69-78

Schönfeld M, Girbig G, Sturn H (1977) Beitrige zur Populationsdynamik der Schleiereule, Tyto alba. Hercynia 14:303-351

Serrano D, Tella JL, Ursúa E (2005) Proximate causes and fitness consequences of hatching failure in lesser kestrels Falco naumanni. J Avian Biol 36:242-250

Stokes AW (1950) Breeding behavior of the Goldfinch. Wilson Bull 62:107-127

Taylor IR (1993) Age and sex determination of Barn Owl Tyto alba alba. Ringing Migr 14:94-102

Taylor IR (1994) Barn owls: predator-prey relationships and conservation. Cambridge University Press, Cambridge

Thomson DL, Monaghan P, Furness RW (1998) The demands of incubation and avian clutch size. Biol Rev 73:293-304

Tinbergen JM, Dietz MW (1994) Parental energy expenditure during brood rearing in the Great tit (Parus major) in relation to body mass, temperature, food availability and clutch size. Funct Ecol $8: 563-572$

Vickery WL, Bider JR (1981) The influence of weather on rodent activity. J Mammal 62:140-145

Weatherhead PJ (2005) Effects of climate variation on timing of nesting, reproductive success, and offspring sex ratios of redwinged blackbirds. Oecologia 144:168-175 